\title{
Granular cell tumor in breast: a case report
}

This article was published in the following Dove Press journal:

Breast Cancer - Targets and Therapy

II April 2017

Number of times this article has been viewed

\section{Maria Castillo Lara \\ Antonia Martínez Herrera \\ Rafael Torrejón Cardoso \\ Daniel Maria Lubián López}

Department of Obstetrics and Gynecology, Hospital Universitario Puerto Real, Cádiz, Spain
Correspondence: Maria Castillo Lara Department of Obstetrics and Gynecology, Hospital Universitario Puerto Real, Carretera Nacional IV, Km. 665, II 110 Puerto Real, Cádiz, Spain Tel +3495600 5000

Email mariacastillo.747@gmail.com
Abstract: Granular cell tumor (GCT) is a rare neoplasm of the soft tissues, and $<1 \%$ of all GCTs are malignant. It usually appears in the tongue and sometimes may affect the female breast. Initially, GCT was considered to be a myogenic lesion affecting female breast (myoblastoma). Actually, it is assumed as a tumor originating from perineural or putative Schwann cells of peripheral nerves or their precursors that grows in the lobular breast tissue, due to the immunohistochemical features. Here, we review the importance of differentiating between this tumor and malignant breast carcinoma. Mammographically, by ultrasound scan and clinically, this case appears to be a malignant tumor of the breast, but with a correct and precise diagnosis including histopathologic examination and immunohistochemical studies, it was correctly identified as a GCT.

Case details: We present a case of a 52-year-old premenopausal woman. This report is of interest because of patient's familial oncologic history and personal history of gynecologic cancer. This rare tumor of the breast and the special way to approach the tumor by local anesthesia makes it interesting to communicate.

Conclusion: This is a case of interest because GCT located in the breast is very unusual and knowledge of GCT is required for the differential diagnosis with breast cancer.

Keywords: carcinoma, S-protein, calretinin, PAS diastase, local anesthesia

\section{Introduction}

Granular cell tumor (GCT) is a benign rare tumor that usually affects the head and neck (most frequent place seems to be the tongue) ${ }^{1}$ and sometimes also appears in the female breast ( $6 \%-8 \%$ of the GCTs are diagnosed in the breast), and is mostly benign. GCT was first identified in the tongue in 1854 by Weber ${ }^{2}$ and then described in the breast by Abrikossoff. ${ }^{3}$ Initially, GCT was considered to be a myogenic lesion affecting the female breast (myoblastoma). ${ }^{3}$ Actually, it is assumed as a tumor originating from perineural or putative Schwann cells of the peripheral nerves or their precursors that grows in the lobular breast tissue, due to the immunohistochemical features. ${ }^{4,5}$ Although most of the GCTs are benign, $<1 \%$ of cases, including those of the breasts, are malignant. ${ }^{6}$ Sometimes, GCT can also appear in the pectoral muscle mimicking breast cancer in females. ${ }^{7}$

GCT of the breast is uncommon (1 GCT in 1000 cases of breast cancer), and it is difficult to identify because it mimics carcinoma clinically and radiologically; this is the reason why it is misdiagnosed. Usually, it appears as a painless rounded nodule and is mobile. This is why it is initially diagnosed as a fibroma or carcinoma. This lesion should be differentiated from carcinoma in order to apply the best treatment option. Some GCTs 
of the breast have been documented to be coexisting with an ipsilateral infiltrating ductal carcinoma ${ }^{8-10}$ and also as a lesion occurring in mastectomy scars. ${ }^{11}$ The most frequent location is the upper-middle and medial quadrant, and the most frequent positive receptors are S-protein, periodic acid-Schiff (PAS) and diastase. ${ }^{9,10}$ It is more common in middle aged, premenopausal, black women and is extremely rare in male patients. ${ }^{3}$

\section{Case report}

The patient a 52-year-old premenopausal woman, was selected from the mammography screening program for breast cancer, and then was requested to do an ultrasonography and a biopsy of the lesion. A written informed consent was provided by the patient to have the case details published. She had a family history of carcinoma, with her father having non-small cell lung cancer and a brother and a sister having colon adenocarcinoma, and a personal history of mucinous borderline ovarian tumor treated in 2013 with laparoscopic-assisted hysterectomy, adnexectomy, and pelvic lymphadenectomy. The patient had also undergone surgery for colon hyperplastic polyps. At that time, the patient was experiencing a perimenopausal syndrome.

Physical examination showed a nodule of $1 \times 1 \mathrm{~cm}$ at the left breast, which was hard and mobile, not adherent to deep layers, in the retroareolar region, at the union of lower quadrants. Only one adenopathy was palpable in the axilla and it had a noninfiltrative but a reactive aspect. The right breast and axilla were both normal, without showing signs of disease. Mammography of the screening program for breast cancer showed a nodule in the left breast the Breast Imaging Reporting and Data System, category 3. Ultrasonography confirmed it as a retroareolar solid nodule with a maximum diameter of $11.6 \mathrm{~mm}$ (Figure 1).

Initially, the mass was considered breast carcinoma and a biopsy was requested to confirm whether it was breast carcinoma or a benign tumor. A biopsy was carried out (Figure 2) and a histologic examination (Figure 3 ) of the biopsy suggested GCT, and deferred immunohistochemical examination showed the typical receptors of this tumor (Table 1). In our case, GCT showed positive immunoreaction to PAS, PAS diastase and S-100, and calretinin and negative immunoreactivity against cytokeratin, estrogen, progesterone receptors, and also to HER2/Neu receptors; also, negative receptors for cytokeratin confirmed the diagnosis of GCT. ${ }^{12,13}$

Finally, a biopsy of a lymph node in the left axilla, followed by a histologic examination showed no signs of malignant cells.

\section{Discussion}

In this study, we sought to examine and clarify the differential diagnosis of a 52-year-old female with GCT of the breast and provides a review of the literature about it. Initially, GCT was considered to be a myogenic lesion affecting female breast (myoblastoma), ${ }^{9}$ was actually assumed to be a tumor originating from perineural or putative Schwann cells of the peripheral nerves or their precursors ${ }^{5}$ that grows in the lobular breast tissue, due to the immunohistochemical features. GCT is usually described as a benign tumor since $<1 \%$, including those of the breast, is malignant. ${ }^{10}$ Sometimes, GCT can also appear in the pectoral muscle mimicking breast cancer in females. Mammographically, clinically and by ultrasound scan, this case appeared to be a malignant tumor of the breast,

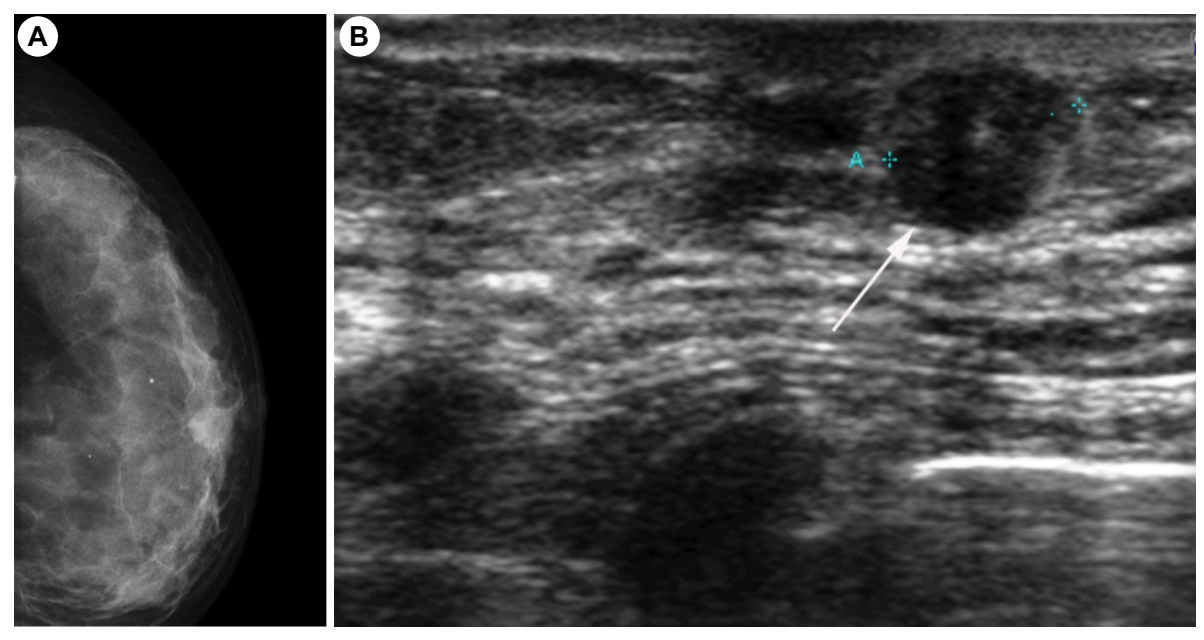

Figure I Mammographic and sonographic appearance of the breast.

Notes: (A) Mammography of left breast, craniocaudal view, shows a nodule in the upper inner quadrant. (B) Ultrasound shows a defined hypoechoic nodule (arrow) with echogenic halo, difficult to differentiate from a malignant breast lesion. 

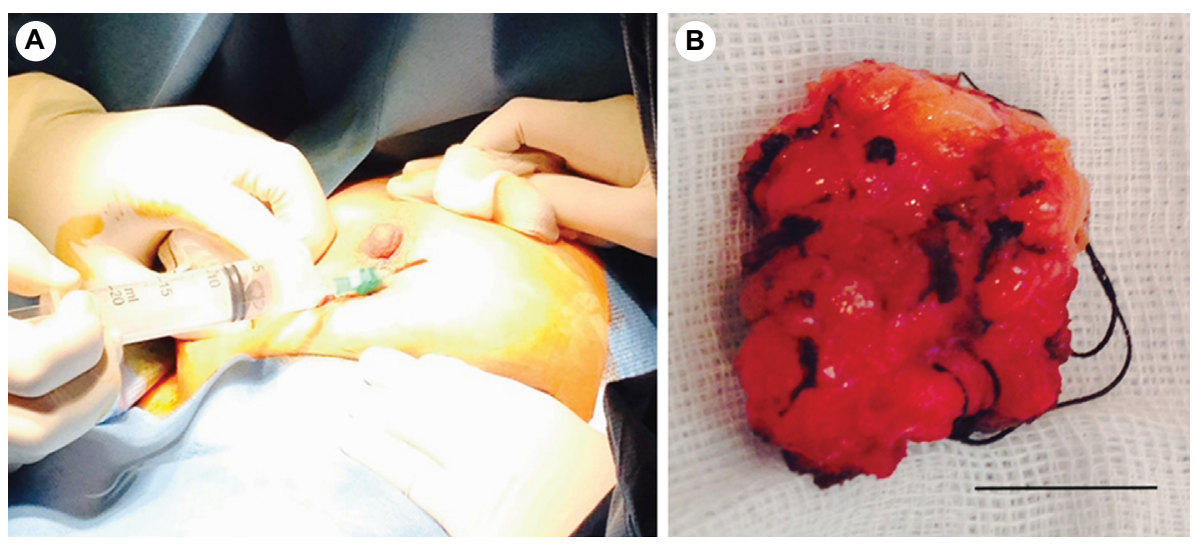

Figure 2 Breast biopsy under local anesthesia.

Notes: (A) Biopsy of the lesion in the left breast under local anesthesia. (B) Macroscopic view of the tumor. Scale bar=l mm.
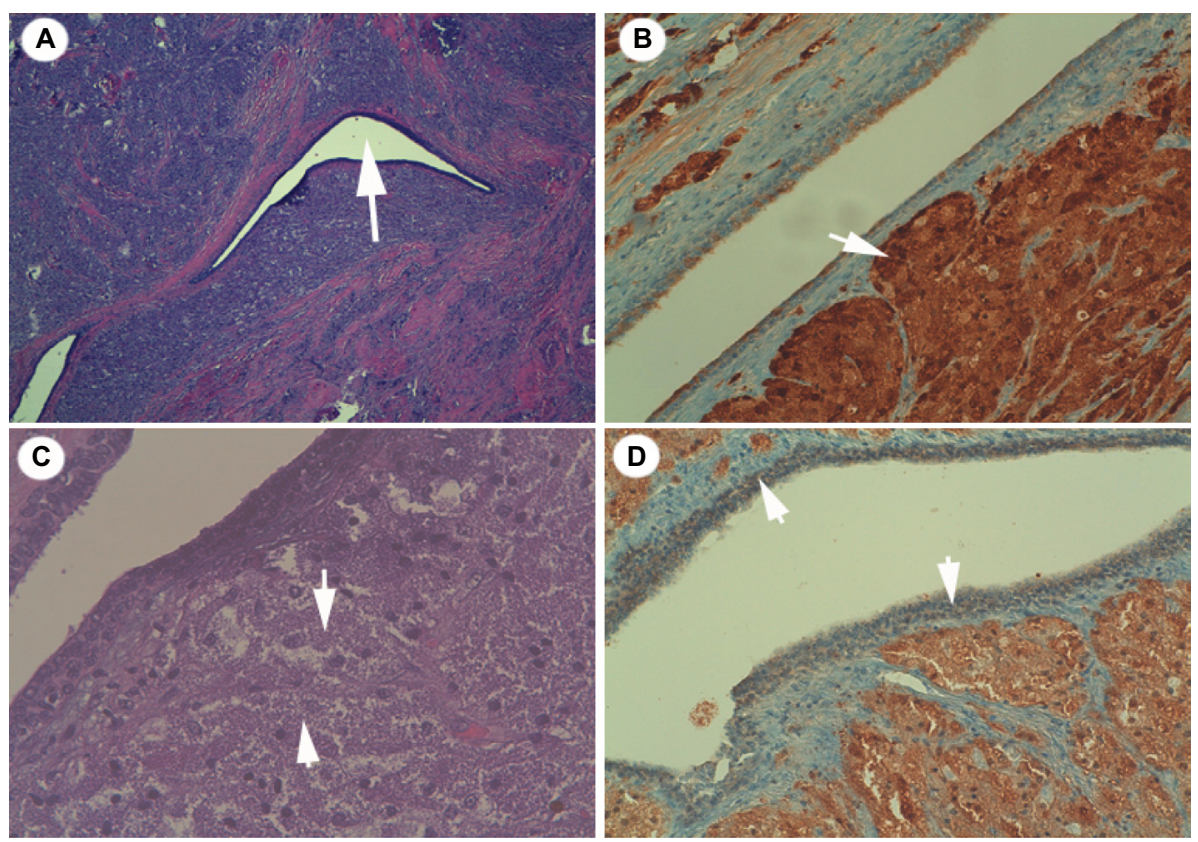

Figure 3 Histopathologic section of the granular cell tumor in the breast.

Notes: (A) Hematoxylin and eosin staining of granular cells in a lobular duct of the breast (arrow; 40x magnification). (B) Hematoxylin and eosin staining of the breast tissue showing large polygonal granular cells and cytoplasm and rounded nuclei (arrow; 200× magnification). (C) PAS- SI00 staining displaying positive activity on the granular cells, highlighting cytoplasmic granularity (arrows; 200× magnification). (D) Calretinin staining showing positive activity on the granular cells (arrows) near to the hyperplasic epithelium (200× magnification).

Abbreviation: PAS, periodic acid-Schiff

Table I Immunochemical staining of the granular cell tumor of breast

\begin{tabular}{ll}
\hline Immunohistochemical markers & Immunostaining intensity \\
\hline S-I00 & ++ \\
PAS & ++ \\
PAS diastase & ++ \\
Estrogenic receptors & - \\
Progesterone receptors & - \\
HER2/Neu receptors & - \\
Calretinin & + \\
Cytokeratin & - \\
\hline
\end{tabular}

Note: $(++)=$ strong, $(+)=$ weak, $(-)=$ negative.

Abbreviation: PAS, periodic acid-Schiff. but with the correct histologic examination, it seemed to be a GCT. Excisional biopsy carried out under local anesthesia, and posterior immunohistochemical examination confirmed the diagnosis of GCT.

It is important to differentiate between this tumor and breast carcinoma because although they have similarities in the diagnosis, the treatment approach (in our case under local anesthesia) and prognosis are very different. This case is of interest due to the patient's familial oncologic history and personal history of gynecologic cancer with this rare benign tumor (GCT) and also the special approach of the tumor by 
local anesthesia. It is interesting to find positive expression of calretinin in these tumors as a new useful marker to differentiate it from others; this has been recently described and has not been used before. Our histopathologic study showed cells with membrane and cytoplasmic granulation with microvesicles, microtubules, and myelin formations (Figure 3); these are oval cells with eosinophilic cytoplasm and the nuclei are small, round, located centrally, and some cells may have more than one.

Some studies carried out till date to analyze the reactivity of GCT against calretinin indicate controversial results. ${ }^{13-15}$ Fine and Li suggested interaction between calretinin expression and the squamous epithelium and the tumor cells. ${ }^{15}$ Jiménez-Herrero et al concluded that calretinin is a useful marker for the diagnosis of GCT, due to the existence of an immunostaining intensity gradient when the tumor is close to the squamous epithelium, especially when hyperplasia is present, which is usual in GCT. ${ }^{13}$

\section{Conclusion}

The knowledge of the GCT located in the breast is required for the differential diagnosis with breast carcinoma. It is assumed that the expression of calretinin, a primarily neuronal protein, supports the neural origin or derivation of these lesions; although a non-neural variety may also occur. ${ }^{16}$ Calretinin expression, in addition to $\mathrm{S}-100$ protein, has been found to be a useful diagnostic marker for GCTs.

\section{Acknowledgment}

The authors would like to thank Dr Muñoz Arias, MD Anatomic and Clinical Pathology from the University Hospital of Puerto Real for her help in histologic and immunochemical studies.

\section{Disclosure}

The authors report no conflicts of interest in this work.

\section{References}

1. Patel A, Lefemine V, Yousuf SM, Abou-Samra W. Granular cell tumour of the pectoral muscle mimicking breast cancer. Cases J. 2008;1(1):142.

2. Weber $\mathrm{CO}$. Anatomische Untersuchung einer hypertrophischen Zunge nebst Bemerkungen über die Neubildung quergestreifter Muskelfasern [Anatomical examination of a hypertrophic tongue as well as remarks on the new formation of transverse muscle fibers]. Virchows Arch A Pathol Anat. 1854;7:115-125. German.

3. Abrikossoff AI. Weitere Untersuchungen über Myoblastenmyome. Virchows Arch Pathol Anat Physiol Klin Med. 1931;280:723-740.

4. Becelli R, Perugini M, Gasparini G, Cassoni A, Fabiani F. Abrikossoff's tumor. J Craniofac Surg. 2001;12(1):78-81.

5. Le BH, Boyer PJ, Lewis JE, Kapadia SB. Granular cell tumor: immunohistochemical assessment of inhibin-alpha, protein gene product 9.5, S100 protein, CD68, and Ki-67 proliferative index with clinical correlation. Arch Pathol Lab Med. 2004;128(7):771-775.

6. Ordóñez G, Mackay B. Granular cell tumor: a review of the pathology and histogenesis. Ultrastruc Pathol. 1999;23(4):207-222.

7. Barnes L, Eveson JW, Reichart P, Sidransky D, editors. World Health Organization Classification of Tumours. Pathology and Genetics of Head and Neck Tumours. Lyon: IARC Press; 2005.

8. Gordon AB, Fisher C, Palmer B, Greening WP. Granular cell tumour of the breast. Eur J Surg Oncol. 1985;11(3):269-273.

9. Tran TA, Kallakury BV, Carter J, Wolf BC, Ross JS. Coexistence of granular cell tumor and ipsilateral infiltrating ductal carcinoma of the breast. South Med J. 1997;90(11):1149-1151.

10. Pergel A, Yucel AF, Karaca AS, Aydin I, Sahin DA, Demirbag N. A therapeutic and diagnostic dilemma: granular cell tumor of the breast. Case Rep Med. 2011;2011:972168.

11. Rosso R, Scelsi M, Carnevali L. Granular cell traumatic neuroma: a lesion occurring in mastectomy scars. Arch Pathol Lab Med. 2000;124(5): 709-711.

12. Torrijos-Aguilar A, Alegre-de Miquel V, Pitarch-Bort G, Mercader-García P, Fortea-Baixauli JM. Tumor de células granulares cutáneo: análisis clínico-patológico de treinta y cuatro casos [Cutaneous granular cell tumor: a clinical and pathologic analysis of 34 cases]. Actas Dermosifiliogr. 2009; 100(2):126-132. Spanish.

13. Jiménez-Herrero E, Hervás-Marín D, Vera-Sempere FJ. Expresión de calretinina en el tumor de células granulares: análisis del gradiente de intensidad en la inmunotinción con correlación clínico-patológica [Expression of Calretinin in the granular cell tumor: analysis of the gradient of intensity in immunostaining with clinical-pathological correlation]. Rev Esp Patol. 2014;47(3):149-155. Spanish.

14. Vered M, Carpenter WM, Buchner A. Granular cell tumor of the oral cavity: updated immunohistochemical profile. J Oral Pathol Med. 2009; 38(1):150-159.

15. Fine SW, Li M. Expression of calretinin and the alpha-subunit of inhibin in granular cell tumors. Am J Clin Pathol. 2003;119(2):259-264.

16. Lester SC, Hicks DG. Diagnostic Pathology: Breast. 2nd ed. Salt Lake City, Utah: Amirsys Elsevier; 2016.
Breast Cancer - Targets and Therapy

\section{Publish your work in this journal}

Breast Cancer - Targets and Therapy is an international, peerreviewed open access journal focusing on breast cancer research, identification of therapeutic targets and the optimal use of preventative and integrated treatment interventions to achieve improved outcomes, enhanced survival and quality of life for the cancer patient.

\section{Dovepress}

The manuscript management system is completely online and includes a very quick and fair peer-review system, which is all easy to use. Visit http://www.dovepress.com/testimonials.php to read real quotes from published authors. 